Fostering digital literacy and German language with the use of digital learning games in the middle school

Daiana Dociu, Ingrid Mihuț-Kert 


\title{
Fostering digital literacy and German language with the use of digital learning games in the middle school
}

\author{
Daiana Dociu ${ }^{a^{*}}$, Ingrid Mihuț-Kert ${ }^{\mathrm{b}}$ \\ ${ }^{a}$ Department of Pedagogy and Didactics in German Language, Faculty of Psychology and Educational Science, Babeş-Bolyai University, Motilor \\ 11 Street, 400001,Cluj-Napoca \\ ${ }^{b}$ Master's Program "Didactics of German language and literature, German culture and civilization of Central and South-Eastern Europe", Faculty \\ of Psychology and Educational Science, Babeş-Bolyai University, Cluj-Napoca, 11 Motilor Street, 400001, Romania \\ *Corresponding author: ana.dociu@ubbcluj.ro
}

\section{Abstract}

Keywords:

education; digital media; media literacy; german language; digital learning games.
In this article, fostering the German language using digital learning games plays the central role. The endless possibilities of digital media and tools for language acquisition offer teachers and learners the opportunity to learn a foreign language creatively, playfully, in a fascinating way and with a certain degree of facilitation in teaching. Through our research we tried to prove the priority of digital media in the field of education and formation. We selected as the target group of the research the pupils of two fifth grades, who learn German as a foreign language in a Romanian school. The use of the chosen learning game led to a considerable increase in the participation of the students in German lessons, created a suitable learning atmosphere in the room and increased the motivation of the participants. The results of this research prove what we expected for the relationship between German lessons and the use of digital learning games in the classroom.

\section{Zusammenfasung}

\section{Schlüsselworte:}

Bildung und Erziehung; Digitale

Medien; Medienkompetenz;

Deutsch; digitale Lernspiele.
Im vorliegenden Artikel spielt die Förderung der deutschen Sprache anhand digitalen Lernspiele die zentrale Rolle. Unendliche Einsatzmöglichkeiten der digitalen Medien und Werkzeugen beim Spracherwerb bieten den Lehrenden und Lernenden die Gelegenheit an, kreativ, spielerisch, faszinierend und mit einer gewissen Erleichterung der Unterrichtsgestaltung eine Fremdsprache zu lernen. Mit unserer Forschung versuchen wir die Wichtigkeit digitaler Medien im Bereich der Bildung und Erziehung zu beweisen. Wir haben als Zielgruppe der Forschung die Schüler zweier fünften Klassen, die Deutsch als Fremdsprache an einer rumänischen Schule lernen ausgewählt. Die Anwendung des ausgewählten Lernspieles brachte zu einer erheblichen Zunahme der Beteiligung der Schüler im Deutschunterricht, erzeugte eine passende Lernstimmung im Raum und stieg die Motivation der Teilnehmer. Die Ergebnisse der vorliegenden Forschung beweisen das, was wir auch erwartet haben an der Beziehung von Deutschunterricht und dem Einsatz digitaler Lernspiele im Unterricht.

\section{Introduction}

Nowadays, when we want to send someone a message, the easiest and closest thing to do is to take the cell phone out of our pocket and type the words on it. The digital menu offers us on different devices such as the cell phone, the tablet, the computer the infinity of exploring the digital world. In order to find the paths that lead us to our goal, people need to encourage and to promote media skills from an early age. To do this, you need to know what digital media literacy means and which tools can be used to practice it. Not only everyday life, leisure time or communication can be influenced by the mediatized world, but also school education, teaching and learning. Everything that means digital is developing rapidly and is constantly increasing. In order to achieve the best understanding and use of the information, tools, platforms, search engines, movies, photos, social networks or applications offered, teachers who want to use different digital instruments in their lessons should develop their media skills themselves, try the digital tools themselves and clarify the expectations of a computer-based teaching in order to acquire the desired competencies at the end of the lesson. Books, lectures, workbooks are the traditional media that offer students access to information. The Internet and the technology used in most of the schools in urban Romania enable learning anywhere, anytime, with a wide range of information available to teachers and learners in all areas. Along with other subjects, foreign language teaching takes part in the use of technology in the domain of teaching and learning. The digital tools are among the most efficient teaching methods 
that awake interest and curiosity in the learner, but also control attention and active participation in the classroom.

This research examines the expected results of media use using the Kahoot! application with the students of a 5th grade, at two different groups, which learn German as a second language in a Romanian school. We will also mention the general conditions for the use of digital tools in German lessons and describe the application we have chosen for the research.

\section{Digital media and the fostering of media literacy in the classroom}

In this article, the fostering of the German language using digital tools plays the central role. The endless possibilities of using digital media and tools for learning a language offer teachers and learners the opportunity to learn a foreign language creatively, playfully, in a fascinating way and with a certain degree of facilitation in teaching. A pedagogically successful use of media happens after the teacher has redefined their role in digital teaching. First, however, as a teacher you should deal with the definitions of the following terms: digital media, media education, media didactics, media education work and media literacy. After deciding whether or not you are media literate, the teacher can jump to the next steps, set teaching goals and try out suitable digital teaching tools that can be used as a way of achieving the goals and as a creative method in the classroom.

First of all, we want to echo a brief explanation of the term "media education". Media education contains all theories and studies that deal with the role of the media in the formation, education and socialization. The term refers to pedagogy and educational science. From 1990 the term "media education" was used more often, which takes place as a lifelong educational process. The term "education" enables participation in culture, with media education clarifying cultural techniques and leading to broad literacy. (Süss, 2018)

Furthermore, we want to emphasize the importance of the use of digital devices by children and young people. For decades, digital devices have been one of the top things on young people's wishlists. Almost every child holds a smartphone in their hand and feels more confident with it. Unfortunately, young adults cannot always develop media literacy on their own. They just use cool applications that involve them in a virtual society, play digital games with friends and often pointlessly explore the virtual world of the Internet. The smartphone emerges as the most important technical device that adolescents and children possess. Proof of this is the following quote from a young woman entitled "What makes young people tick in 2016?" (Calmbach, 2016):

\begin{abstract}
"My sister used to say [...] you used to make phone calls in these phone booths. Just think how sick it must be to put coins in this machine. I don't know, I can't imagine that. I just can't imagine that you don't have a phone in your pocket. Imagine something happens or I'm bored on the street. What am I doing?!" (Female, 16 years)
\end{abstract}

First of all, the smartphones are used by children and young people to communicate. Whether you talk to your parents, grandparents, colleagues, friends or strangers using smartphones, the device plays the most important role in socialization. Settings for different applications make it possible for users to stay permanently connected without having to log out. This simple attitude unfolds the fear of missing something, the so-called FOMO, the fear of missing out and forces the person involuntarily to remain logged in in order not to be thrown outside of a group of people. Digital participation replaces social participation, so that the smartphone plays an important role in the function of social back-up. (Calmbach, 2016)

So that other roles of digital devices can also be discussed among children and young people, teachers are taking an important role in the digital world today. Firstly, media literacy is promoted among adults, so that later on, together with the teachers, they can use the world of the Internet in a targeted manner and have fun with it. Using digital media and digital tools in the classroom is a major challenge for teachers. One tries not only to promote digital media literacy as a central prerequisite for social participation among children and young people, but also to achieve other important goals of the lifelong learning process with it. The importance of digital media literacy in various future professions must be taken into account by parents and teachers. The opinion of a young man speaks for it (Calmbach, 2016):

\begin{abstract}
"Of course it depends on what kind of job you choose. Of course, if I'm a craftsman now, it doesn't really matter that much, unless I want to google it 'bird house'. Otherwise, if you are working on the computer. That's why I would also like, because there are so many office jobs, that teachers do that more in class, but they just don't do it."(Male, 14 years old)
\end{abstract}

In order to promote media competence as a key competence for the professional success of young 
adults, one needs to replace the old media with the new ones in different subjects and to meet the expectations of the young learners.

But what are digital media and how can we use them in the classroom? In didactic terms, digital media are instruments, teaching and learning objects that support the learning and teaching process. Each digital media offer has different characteristics that play an important role in the classroom. The content, the process structures, the interactivity properties and the objectives are some of them that influence the choice of users and their use in the classroom. (Herzig, 2014)

Visual and auditory forms can be distinguished in terms of learning success. In his work, Professor Herzig mentions important effects of digital media use on the level of the individual, which build up a higher learning success in terms of "knowledge acquisition, problem-solving ability and transferability" (Herzig, 2014):

- Information is presented as text and images, instead of being presented only as text,

- Illustrations for a text are presented as annotated illustrations, instead of illustrations without descriptions

- Information is presented integrated in text and image (in spatial proximity to one another), instead the text being presented before the illustrations.

These are pictures and illustrations in lessons that use digital media and the content of digital tools to promote learning, make learning fun and increase media literacy in learners. In order to expect a higher learning success, according to Herzig, the following can be taken with regard to sensory modalities (Herzig, 2014):

- Information is presented aurally (as spoken text) and visually (as an image or as animation), as if it is only presented visually (as written text and as an image or as animation) or only aurally (as spoken text);

- Information is presented aurally (as spoken text) and visually (as animation) simultaneously, as if it were presented aurally (as spoken text) and visually (as animation) one after the other;

- Information is presented visually (as written text and as animation) in spatial proximity to one another (integrated), as if it was presented spatially separately.

Using auditory and visual information interactively in the classroom requires a digitally furnished room and digital tools that serve as instruments in the class. In order to offer a constructive use of media to children as well as to young people and adults, one needs to promote media literacy in schools and educational institutions. This will also weaken the negative effects of the media on society and the new media will become more valuable. The mediatization of everyday life happens in constant change. In order to cope with the development and socialization processes, children, adolescents, but also adults are faced with new challenges. In order to master these challenges, one needs to be able to deal competently with digital networks, forms of communication and media offers. Technological developments prove that media literacy is not a condition that happens once in a lifetime, but belongs to the lifelong learning process. (Süss, 2018)

\section{Digital tools in German lessons}

Numerous applications of digital tools enable teaching and learning and support digital teaching. The Internet is a limitless pool of knowledge that opens the gates to infinite areas and reveals the paths to both technical and media skills. Five important theses should be kept in mind when setting up digital teaching (Hirsch, 2020, p. 16-17):

- "Digital teaching" offers access to practically unlimited information;

- Digitally supported teaching offers helpful tools for teaching and learning;

- Network principles are a tailwind for modern education;

- Digitally supported teaching is based on the realities of life of children and adolescents;

- Digitally supported teaching promotes digital maturity and sovereignty.

What is meant by this is the importance of using digital tools in today's classroom. E-learning is slowly becoming part of our school education. Teaching with a game character motivates the learners, relaxes the teaching and learning atmosphere and transforms the dry frontal teaching into an interactive collaboration.

Kahoot! - is a trivia and gaming platform that has become very popular among teachers and students in the recent years. It can be used both in class as a live exercise during class and as a challenge that can be done in a certain amount of time (as a homework, for example). Kahoot! can be used on any device. The teacher can design a variety of activities, games, multiple choices, exercises that can be connected to 
the content of the subject taught in class. Kahoot! also provides a timely report on the response of each student. It also provides a visible ranking for students, which leads to their motivation to reach the podium of the game.

Digital educational games already express a positive meaning by their very concept. The free learning platform Kahoot! offers numerous predefined learning games or the possibility of designing games on different topics both as a teacher and as a student and makes teaching easier in a playful way. The subject, the teacher and the class gain a positive impression during and after the game. Due to its easyto-use structure Kahoot! is also suitable on your own mobile device in schools, where the opportunity to provide a digital device for every student does not exist. Kahoot! offers quizzes with multiple choice questions and a countdown. The quiz app offers the design of learning processes as a game and promotes the gamification of learning. The teacher lets the quiz play on the screen so that all learners can see and follow it. The only movement you have to make is to tap the correct symbol with your finger; otherwise the teacher will moderate the entire course of the game. (Ammenwerth, 2017)

Not only can you have fun while accessing Kahoot! in kindergarten and elementary school, with your grandparents or while traveling, but Kahoot! and other digital learning games are also suitable for teaching at secondary school, high school and also at university, encouraging the use of digital methods in the classroom: "If you use Kahoot in class, you immediately notice: It works." (Wampfler, 2017)

Game-based learning is used as a good practice to involve students in reviewing classroom content. Creating an atmosphere in which students think critically and are involved is essential for student learning and teaching. (Icard, 2014)

But how do digital learning games work in our German lessons? We present in the next chapters of this article the results of our research for using the digital app Kahoot! in the German lessons of two $5^{\text {th }}$ grade classes.

\section{Research methodology}

In the last year, the need to digitize education has become more needed than ever. If until recently the use of computers, tablets or smartphones was an optional issue, or used only during certain classes, the new times have led to an urgency, willy-nilly, but sine qua non, of the digitization of schools. The education that has passed in the online environment has undergone a rapid adaptation and a long-awaited innovation in the school environment. Even if face-toface teaching methods in a classical classroom are desired by most beneficiaries of the learning act, digital methods used successfully in education will remain as a valuable tool in modern, student-oriented teaching, the use of digital technologies leading to an improvement of the educational quality and a completion of the lessons taught.

\subsection{Objectives of the research}

The objectives of the hereby research are to measure the implication, the active participation and the increase of the student's motivation during the German lessons, in which modern educational software like Kahoot! are used.

\subsection{Hypothesis and the variable of the research}

The present study aims to test the hypothesis which emphasizes that the usage of the educational software Kahoot, during the German lessons, leads to a higher implication and active participation among students of the $5^{\text {th }}$ grade.

\subsection{Research sample}

To obtain the above-mentioned data, a $5^{\text {th }}$ grade class of 30 pupils was used as an experimental group, where the Kahoot! app was regularly used. There was also a control group of 29 students in a different 5 th grade class from the same school. The experimental class has 30 students: 9 boys and 21 girls. The control class is formed out of 16 boys and 13 girls, a total of 29 students.

Both classes involved in the research have particularly good students. Most of the students are active and curious. In both classes the students are incredibly involved, without any cognitive problems. One student from the control class is particularly chatty, involved, always wants to answer and to read. Only one student had missed several classes because of personal health problems.

The amount of time provided for the data collection was 3 months, with the students using the app at least once a week during the German classes.

\subsection{The research methods:}

The main research method that was used is the experimental psycho-pedagogical method. This was 
implemented with the help of the observational method, using a follow-up grid for these aspects:

- How many students were able to answer the teacher's question in Kahoot! vs. direct questions?

- How many students ask questions (e.g.: for clarification) vs. how many students find answers on their own after playing the consolidation game?

- How many questions does the teacher ask in the classroom?

\section{Research results}

Using Kahoot! at the experimental class we have concluded that approximately 25 students have managed to respond to every question from Kahoot! (at 10 questions / game), often even using 2 Kahoot! games resulting in even 20 questions per hour.

The number of 25 students out of 30 is due to some technical issues, poor internet connectivity, and to the fact that not all students could access the app.

Concerning the class that was part of the control group, the number of questions that the pupils could answer was one question per pupil, the number of consolidating asked questions reaching 5-6.

After the lesson was finished, the teacher asked 56 questions to verify if the transmitted information was understood. Each question was answered by a random pupil. Thanks to the app, at the experimental class, 25 students managed to answer 10 or 20 questions.

The number of questions asked by the students, after the lesson was taught, was maximum one. At the experimental class, the app was used as a method to verify the new learned knowledge. Although, the students in this class didn't ask questions for clarification purposes either, with the help of the app the answers of the students were reviewed in real time and checked in what proportion these were right or wrong, in order to be able to bring additional explanations. The answers are highlighted in Table 1:
Table 1. The comparison of the target aspects in the experimental and control class

\begin{tabular}{lll}
\hline & $\begin{array}{c}\text { Experimental class } \\
\text { (30 students) }- \\
\text { with Kahoot! }\end{array}$ & $\begin{array}{c}\text { Control-group } \\
\text { (29 student) } \\
\text { without Kahoot! }\end{array}$ \\
\hline $\begin{array}{l}\text { How many students were able to } \\
\text { answer the teacher's question in }\end{array}$ & 25 & 1 \\
$\begin{array}{l}\text { Kahoot! vs. direct questions? } \\
\text { How many students ask } \\
\text { questions (e.g.: for clarification) } \\
\text { vs. how many students find } \\
\text { answers on their own after } \\
\text { playing the consolidation game? }\end{array}$ & 0 & $0-1$ \\
$\begin{array}{l}\text { How many questions does the } \\
\text { teacher ask in the classroom? }\end{array}$ & $10 / 20$ & $5 / 6$ \\
\hline
\end{tabular}

We can notice that approximately 25 students have managed to respond to every question from Kahoot! (at 10 questions / game), often even using 2 Kahoot! games resulting in even 20 questions per hour, comparing to the class that played the role of the control group, the number of questions that the pupils could answer was one question per pupil, the number of consolidating asked questions reaching 5-6.

\section{Discussions and conclusions}

Using the Kahoot! app while teaching has led to a significant increase in the implication of the students during the German classes. Most students from the classroom have asked for Kahoot! every hour. The competition spirit and the playful characteristic of the app has brought a pleasant atmosphere in the classroom and, at the same time, bringing with it benefits like consolidation, improvement, and repetition of the information from a higher number of participating students than during a classic class.

The students were not required to expose themselves in front of the class to ask clarifying questions. Due to the end report that was provided at the end of the game, the teacher was able to observe if there was misunderstood information from the taught lesson and if and where the teacher should intervene.

The students were also able to self-evaluate their performance in real time, learning from their own mistakes and correcting themselves. "Kahoot!" is a very practical learning game, that can be used both as a means to consolidate, to summarize and to exercise, by being a novelty and a breath of fresh air - for both the students and the teacher - that can easily be used in the classroom.

Not just Kahoot!, the learning game chosen by us proves to be a benefit of teaching, but also other digital games can be used as new teaching method, which 
arouse the students' interest and gain the attention of the lesson content.

Both young teachers and the senior teachers are invited to have the courage to apply the new teaching methods in the subjects taught by them and they will have a great result and the topics of their lessons will be a major success.

The new media are the method of an effective long-term learning, starting with the first years in education and continuing throughout life. Digital learning games foster both the digital literacy and the competences requested by each thought subject. This article is the first piece of a larger future research discussing the same topic but applied on a higher sample of students different ages and also teachers from different teaching fields. We wish our research to succeed in motivating as many future and current teachers as possible and convince them to have the courage to apply digital media and new teaching methods in their classes.

\section{Authors note:}

Daiana Dociu is a $\mathrm{PhD}$ student in History at "Doctoral School of Population Studies and the History of Minorities" and associate teacher at the Department of Pedagogy and Didactics in German Language at the Babeş-Bolyai University. Her areas of interest and research include didactics of history and geography, didactics of art, online teaching, teaching with digital media, classroom management and education.

Ingrid Mihuț-Kert is a postgraduate student at the master's degree for "Didactics of German language and literature, German culture and civilization of Central and South-Eastern Europe" at Babeș-Bolyai University in Cluj-Napoca and German Teacher at
„Dimitrie Cantemir” and „George Coşbuc“ secondary school in Baia Mare. Her field of research is: education, new teaching methods, digital media, art, history and languages.

\section{References}

Ammenwerth, E., \& Blank, C. (2017). Alle mal abstimmen! Thematischer Einstieg bei großen Gruppen mit Kahoot. Schwerpunkt: E-Learning Tools. Forum Neuer Medien Austria, pp. 13-15.

Calmbach, M., Borgstedt, S., Borchard, I., Thomas, P., \& Flaig, B. (2016). Digitale Medien und digitales Lernen. pp.176-190, Available at: https://www.researchgate.net/publication/301670254_Di gitale_Medien_und_digitales_Lernen , (accesed at 12.06.2021)

Herzig, B. P. (2014). Wie wirksam sind digitale Medien im Unterricht? im Auftrag der Bertelsmann Stiftung, pp.913 Available at: https://www.bertelsmannstiftung.de/fileadmin/files/BSt/Publikationen/GrauePubl ikationen/Studie_IB_Wirksamkeit_digitale_Medien_im _Unterricht_2014.pdf, (accesed at 14.06.2021)

Hirsch, N. (2021, 06 17). Unterricht digital. Methoden, Didaktik und Praxisbeispiele für das Lernen mit OnlineTools. Mülheim an der Ruhr.

Icard, S. B. (2014). Educational technology best practices. International Journal of Instructional Technology and Distance Learning. Educational technology best practices. 11(3), pp. 37-41. Available at: http://itdl.org/Journal/Mar_14/Mar14.pdf\#page=41 (accesed at 10.03.2021)

Süss, D., Lampert, C., \& Trültzsch-Wijnen, C. (2018). Medienpädagogik. Ein Studienbuch zur Einführung. Wiesbaden: Springer VS, Wiesbaden, pp.1-2,109.

Wampfler, Ph. (2017): Der Kahoot-Sog und die Gefahr der Quizifizierung der digitalen Bildung. Schwerpunkt: ELearning Tools. Forum Neue Medien Austria Magazin, pp.15-17. Available at: https://schulesocialmedia.files.wordpress.com/2017/05/f orum-neue-medien-kahoot-sog.pdf, (accesed at 25.05.2021) 